\title{
IMPROVING STUDENTS' ACHIEVEMENT IN MATHEMATICS THROUGH ONLINE PLATFORM DURING COVID-19 PANDEMIC: A CASE OF REPEATED MEASURES
}

\section{DR. FRANCIS ELOCHUKWU IKEH ${ }^{1}$, DR. DAVID ONYEMAECHI EKEH ${ }^{2}$, DR. ELOM CHINYERE O. ${ }^{2}$, DR. CHUKS MARCEL EZEMONYIH ${ }^{3}$, DR. OMOSOWON VICTORIA OLASOJI ${ }^{5}$, DR. BLESSING CHINYERE ANAKPUA ${ }^{4} \&$ DR. MERCY IFUNANYA ANI ${ }^{2 *}$}

\author{
${ }^{l}$ Department of Science Education, University of Nigeria, Nsukka, Nigeria \\ ${ }^{2}$ Department of Educational Foundations, Alex Ekwueme Federal University, Ndufe Alike Ikwo, Ebonyi State, Nigeria \\ ${ }^{3}$ Department of Vocational Teacher Education, Alex Ekwueme Federal University, Ndufe Alike Ikwo, Ebonyi State, Nigeria \\ ${ }^{4}$ Department of Science Education, Alex Ekwueme Federal University, Ndufe Alike Ikwo, Ebonyi State, Nigeria \\ ${ }^{5}$ Department of Science Education, Enugu State College of Education (Technical) Enugu Nigeria
}

The study investigated on improving students' achievement in mathematics through online platform during covid-19 pandemic: A case of repeated measures. The study adopted one-group time series research design. Sample size of 280 Mathematics students were used for the study from the population of 4263 SS1I Mathematics students in Nsukka education zone of Enugu State, Nigeria. Mathematics Achievement Test was used for the conduct of the study. Face and content validation of the instrument was established. Internal consistency reliability estimate of 92 was obtained using Kuder-Richardson 20 (KR-20) while estimate of stability of 0.88 was obtained. At three weeks interval, the subjects were pretested twice before the experiment and post tested twice after the experiment. In order to address the research questions, the data was analyzed using means and standard deviations, and repeated measure analysis of variance was used to evaluate the hypotheses at the 0.05 level of significance. The study found that students who were exposed to an online platform had higher mean achievement scores than students who were exposed to a traditional (lecture) method.
\end{abstract}

KEYWORD: Online Learning, Pandemic Period, COVID-19, Achievement and Mathematics

Received: Mar 09, 2021; Accepted: Mar 29, 2021; Published: May 05, 2021; Paper Id.: IJMPERDJUN202122

\section{INTRODUCTION}

The outbreak of corona virus also known as COVID-19 has led to the closure of all educational institutions all over the world which Nigeria is not an exceptional. As part of the consequences of the COVID-19 pandemic, schools in Nigeria were closed down in the country following the approval for the closure of all schools for a period of one month by Federal Ministry of Education on March 19th, 2020 which commenced on Monday 23rd March 2020 in order to curtail the spread of the corona virus. Until the closure of schools in March $19^{\text {th }} 2020$, the teaching and learning in schools especially in secondary schools in Nigeria was characterized by students who frequently come in contact with their classroom teachers according to their timetables through formal lecturing (König, JägerBiela \& Glutsch, 2020). In this classroom setting, students are expected to sit and listen to their classroom teachers as he/she delivers his/her instruction (Lipowsky, 2015). 
During the COVID-19 pandemic, schools were put to the test in terms of their ability to deal with issues or circumstances that necessitate the use of technology, such as hardware and software, to allow successful online learning. As a result, the growth of online learning environments has accelerated, ensuring that learning is not interrupted (Kumar as cited in Mukhtar, Javed, Arooj \& Sethi, 2020). Keeping education continuity in mind, there is a pressing need in many parts of the world, including Nigeria, to move away from classroom teaching and learning and toward the adoption of online learning teaching. According to UNESCO (2020), most countries rushed into online distance education using online platforms, causing an unplanned and rapid change in the educational sector.

Training that takes place over the internet is referred to as online teaching and learning. Both teachers and students profit greatly from online education. It is a set of teaching and learning resources aimed at improving students' learning experiences by incorporating computers, ICT tools, and the internet into the learning and teaching process (Baig, 2011). Online teaching and learning is uniquely designed to reach and engage the modern learner on a one-to-one basis anywhere and at any time, regardless of venue (Sadiku, Adebo \& Musa, 2018). Online learning allows students to have more versatility in terms of time and space, as well as increased connectivity and interaction (Anderson, 2004). Online learning has been put to the test in order to meet the needs of an increasing number of students who are unable to engage in conventional classroom settings (Stern, nd). This may be why Christensen, Horn, and Johnson (2008) provide a convincing case for transforming education to make much more use of online technologies in order to provide more student-centered and individualized instruction.

These students include those who are unable to attend traditional classroom classes, those who are unable to locate a specific class at their preferred institution, those who live in remote areas, those who work full-time and can only study at or after work, and those who choose to learn on their own (Stern, n.d). Online teaching, according to Sadiku et al (2018), provides time and space comfort, cost-effectiveness, and versatility. The authors went on to say that online learning helps students to receive a globally recognized degree without having to attend physical courses, as is the case in traditional classrooms. According to Means, Toyama, Murphy, Bakia, and Jones (2010), online learning has grown in popularity and is being used by instructors because of its ability to provide instructors with more flexible access to content and guidance at any time.

As summarized by Yusnilita (2020), some of the main advantages of online learning include convenience, enhanced learning (it increased understanding of course content, more meaningful discussions, emphasis on writing skills, technology skills, and life skills such as time management, independence, and self-discipline), interaction (it increases student-teacher and student-student interaction and discussion), and convenience (it increases enrollments of students).Furthermore, online learning has been shown to improve students' success in Science (Ugwuanyi et al., 2020a, 2020b, 2020c, 2020d; Ugwuanyi et al., 2019a, 2019b, Ugwuanyi \& Okeke, 2020); Mathematics (Onah et al., 2020), and Social Science courses (Ejimuonye et al., 2020a, 2020b). Based on these considerations and findings of other researchers on the improved impact of online teaching, the researchers explored the impact of an online teaching platform on students' academic achievement in Mathematics as a means of teaching and learning during the pandemic using repeated steps.

\section{MATERIALS AND METHOD}

The study employed one-group time series research design. The design according to Ugwuanyi et al (2019b) is an experiment which allows there searcher to pre-test and post-test the subjects in more than one occasion. This research was 
carried out in Enugu State, Nigeria, in the Nsukka education district. The Nsukka education zone was made up of three Local Government Areas (LGAs): Nsukka, Igbo-Etiti, and Uzo-Uwani. There are 58 secondary schools in the district, which are divided as follows: Nsukka has 30 high schools, 16 secondary schools in Igbo-Etiti, and 12 secondary schools in Uzo-Uwani (Planning, Research and Statistics Department, Post Primary School Management Board, Nsukka, Enugu State).

In this report, 3795 SS2 Mathematics students from all 58 government-owned senior secondary schools in the Nsukka education zone were included as the population. The study used a sample size of 280 SS2 Mathematics students in the Nsukka education district. A multistage sampling procedure was used to drawn the sample.

The researchers developed the Mathematics Achievement Test (MAT) as the data collection tool. The test consists of 50 multiple choice questions, each with four possible answers ranging from A to D. Correct responses received one mark, while incorrect responses received none. The instrument's face and material validation were calculated. The instrument was issued to three experts in the Department of Science Education (Mathematics Education and Measurement and Evaluation units) at the University of Nigeria, Nsukka, to ensure face validation. The experts were asked to examine the instrument for structure and consistency of the questions, as well as whether the questions' answers corresponded to the ones in the labeling and whether the questions matched the table of specifications. Meanwhile, a well-constructed table of specifications based on Bloom's taxonomy of education's six stages of cognitive domain was used to ensure material validation of the instrument.

The instrument's internal consistency was calculated by giving twenty (20) copies to SSII Mathematics students at Nsukka High School in Nsukka, Nigeria, which was not part of the study's sampled school. Since the instrument was dichotomously scored, the students' answers were subjected to Kuder-Richardson 20 (KR-20), which yielded a reliability coefficient of.92.Estimate of internal stability was also established using Pearson Product Moment Correlation (PPMC) and the reliability estimate of 0.88 was obtained.

A simple random sampling technique was used to divide the subjects into treatment and control groups during the experiment. The experimental students were taught using an online instructional system, while the control students were taught using a traditional (lecture) method. Pretests were given to the Mathematics students in the two groups on two separate occasions prior to the start of the treatment to assess their level of achievement before the experiment. The experiment lasted six weeks. Students in the control group were taught using lesson notes based primarily on the lecture process, while students exposed to online instructional methods were given the task of planning assignments in groups and sharing them via Google Docs, after which they submitted them via Moodle Learning Management System (LMS). At the end of the fourth week, the same instrument developed for the study was administered to the students in the two groups as posttest 1 while posttest 2 was administered to the students at the end of the experiment in the 6th week. In order to answer all of the research questions, the data was analyzed using mean and standard deviation, while repeated measure analysis of variance (ANOVA) was used to test the null hypothesis at the. 05 level of significance.

\section{RESULTS}

\section{Research Question}

What are the average achievement scores of students who were taught Mathematics through an online instructional system and those who were taught through a traditional (lecture) method? 
Table 1: Mean and Standard Deviation of Students' Achievement in Mathematics before and After Treatment

\begin{tabular}{|l|c|c|}
\hline Measures & Mean & Std. Dev. \\
\hline Pre-test 1 & 13.28 & 5.77 \\
\hline Pre-test 2 & 14.65 & 6.62 \\
\hline Post-test 1 & 41.23 & 8.67 \\
\hline Post-test 2 & 44.46 & 9.03 \\
\hline
\end{tabular}

The pre-test means achievement scores of students in the two instances varied, according to the results of the study in Table 1. $(\mathrm{M}=13.28 \pm 5.77 ; \mathrm{M}=14.65 \pm 6.62)$. Similarly, the post-test achievement scores of Mathematics students in the two different occasions also differed $(\mathrm{M}=41.23 \pm 8.67 ; \mathrm{M}=44.46 \pm 9.03)$. The result indicated that teaching Mathematics with the use of online platform enhances students' achievement compared to conventional (lecture) method.

\section{Hypothesis}

The mean achievement scores of Mathematics students exposed to online instructional methods and those exposed to traditional (lecture) methods are not significantly different.

Table 2: Repeated Measure Analysis of Variance for the Effect of Online Platform on Students' Achievement in Mathematics

\begin{tabular}{|c|c|c|c|c|c|c|c|}
\hline & Source & $\begin{array}{l}\text { Type III Sum of } \\
\text { Squares }\end{array}$ & Df & Mean Square & $\mathbf{F}$ & Sig. & $\begin{array}{c}\text { Partial Eta } \\
\text { Squared }\end{array}$ \\
\hline \multirow{4}{*}{ Measures } & Sphericity Assumed & 278002.014 & 3 & 92667.338 & 441.963 & .000 & .843 \\
\hline & Greenhouse-Geisser & 278002.014 & 1.501 & 185230.903 & 441.963 & .000 & .707 \\
\hline & Huynh-Feldt & 278002.014 & 1.507 & 184454.362 & 441.963 & .000 & .609 \\
\hline & Lower-bound & 278002.014 & 1.000 & 278002.014 & 441.963 & .000 & .380 \\
\hline \multirow{4}{*}{ Error } & Sphericity Assumed & 175495.486 & 837 & 209.672 & & & \\
\hline & Greenhouse-Geisser & 175495.486 & 418.734 & 419.109 & & & \\
\hline & Huynh-Feldt & 175495.486 & 420.497 & 417.352 & & & \\
\hline & Lower-bound & 175495.486 & 279.000 & 629.016 & & & \\
\hline
\end{tabular}

Table 2 shows that the online platform had a major impact on students' achievement in Mathematics; F (3, 279) = 441.963, $\mathrm{p}=.000$. As a result, the null hypothesis of no substantial difference was found to be false. This is due to the fact that the exact likelihood value (.000) is less than the 0.05 amount of significance. As a result, the researchers conclude that there is a substantial difference in the mean achievement scores of Mathematics students who received online instruction versus those who received traditional (lecture) instruction. Meanwhile, the online teaching approach had a significant impact on students' mathematics achievement $(\beta=0.843)$.

\section{DISCUSSION OF FINDINGS}

The Impact of an Online Instructional Strategy on Students' Math Achievement

Students exposed to an online instructional approach had higher post-test mean achievement scores in Mathematics than students exposed to a traditional (lecture) process, according to the study's findings. The achievement gap was bolstered by repeated measure analysis of variance (ANOVA), which revealed a substantial difference in mean achievement scores between students teaching Mathematics using the online instructional method and those taught using 
the traditional (lecture) method. The implication is that, online instructional method when used in teaching Mathematics is capable of enhancing students' achievement in Mathematics. The finding was not surprising because online teaching according to König, Jäger-Biela and Glutsch, (2020) offers exciting opportunities to expand the learning environment for diverse student populations.

The finding is in consonance with Ljubica (2009) who noted that e-learning is a powerful tool for visualization and simulation of the key notions of mathematics which leads to higher achievement. Navarro and Shoemaker (2000) found that online learners' learning results were on par with or better than conventional learners, regardless of context characteristics, and that students were very happy with online learning. Rovai and Jordan (2004) noticed that students in the blended format had a greater sense of community than students in the traditional format when they investigated the relationship of sense of community between traditional classroom and blended format.

\section{RECOMMENDATION}

The following recommendations were made based on the study's findings:

- Teachers should be introduced to the use of online teaching methods in schools because they have been shown to be successful in improving students' achievement in Mathematics and they are seldom used by classroom teachers.

- As a matter of urgency, the government need to provide basic Information Communication Technology(ICT) Infrastructure to effectively roll out online learning;

- Government need to urgently organize in-service training for secondary school teachers in order to use the ICT tools effectively in their lesson delivery.

- Teachers' and students' readiness in the use of online teaching needs to be fathomed and supported accordingly

\section{CONCLUSIONS}

From the findings of the study, the study concludes that online teaching and learning is highly effective in enhancing the students' academic achievement in Mathematic. This may be attributed to the fact that in an online learning environment, teachers can explain abstract concepts with the help of animation and graphics, thus; developing imagination among students.

\section{ACKNOWLEDGEMENTS}

The researchers appreciate all the research participants for their contributions in this research paper especially Dr. Mercy Ifunanya Ani (ani@funai.edu.ng) who served as the corresponding author for this research study.

\section{REFERENCES}

1. Baig, M. A. (2011). A critical study of effectiveness of online learning on students' achievement. Journal of Educational Technology, 7 (4) 28-33.

2. Ejimonye, J.C., Onuoha, J.C., Ugwuanyi, C.S., Eneogu, N.D., Ugwuanyi, B.E \& Ogbuehu, S.N (2020a). Effectiveness of TwoDimensional Animation Technique in Enhancing Students' Motivation in Quantitative Economics Concepts. International Journal of Future Generation Communication and Networking (IJFGCN), 13(1),27-38. 
3. Ejimonye, J.C., Ugwuanyi, C.S., Okeke, C.I.O., \& Nwoye, M.N. (2020b). Two-Dimensional Animation and Students' Achievement in Mathematical Economics: Implications for Science Teaching. International Journal of Engineering Research and Technology, 13(6), 1220-1230

4. König, J., Jäger-Biela, D. J. \& Glutsch, N. (2020).Adapting to online teaching during COVID-19 school closure: teacher education and teacher competence effects among early career teachers in Germany. Retrieved from https://www.tandfonline.com/doi/full/10.1080/02619768.2020.1809650

5. Lipowsky, F. (2015). Teaching in Educational Psychology. Berlin, Heidelberg: Springer.

6. Ljubica, D. (2009). Applications GeoGebra into teaching some topics of Mathematics at the college level. Retrieved from http://www.doiserbia.nb.rs/img/doi/1820-0214/2009/1820-02140902191D.pdf

7. Means, B., Toyama, Y., Murphy, R., Bakia, M. \& Jones, K. (2010). Evaluation of evidence-based practices in online learning: A meta-analysis and review of online learning studies. Retrieved from https://www2.ed.gov/rschstat/eval/tech/evidence-basedpractices/finalreport.pdf

8. Mukhtar, K., Javed, K., Arooj, M. \& Sethi, A. (2020). Advantages, limitations and recommendations for online learning during COVID-19 pandemic era. Retrieved from https://www.ncbi.nlm.nih.gov/pmc/articles/PMC7306967/

9. Navarro, P., \& Shoemaker, J. (2000). Performance and perceptions of distance learners in cyberspace. American Journal of Distance Education, 14 (2), 15-35.

10. Onah, E.N., Ugwuanyi, C.S., Okeke, C.I.O., Nworgu, B.G., Agwagah, U.V.N., Ugwuanyi, C.C., Obe, P.I., Nwoye, M. N., \& Okeke, A.O. (2020). Evaluation of the Impact of Computer-Assisted Instruction on Mathematics and Physics Students' Achievement: Implication for Industrial Technical Education. International Journal of Engineering Research and Technology, 13(7): 1786-1794. http://irphouse.com/ijert20/ijertv13n7_35.pdf.

11. Rovai, A.P., \& Jordan, H. (2004). Blended learning and sense of community: A comparative analysis with traditional and fully online graduate courses. International Review of Research in Open and Distance Learning, 5 (2), 2-13.

12. Sadiku, M. N. O., Adebo, P. O. \& Musa, S. M. (2018). Online teaching and learning. International Journals of Advanced Research in Computer Science and Software Engineering, 8 (2) 73-75

13. Stern, J. (n.d). Introduction to online teaching and learning. Retrieved from http://www.wlac.edu/online/documents/otl.pdf

14. Ugwuanyi, C.S., Nduji, C.C., Gana, C.S., Nwajiuba, C.A., Ene, C.U., Okeke, A.O., Eseadi, C., Okeke, C.F.(2019b). Effectiveness of flipped classroom instructional technology model in enhancing students' achievement in physics. International Journal of u- and e- Service, Science and Technology, 12(4): 37-46.

15. Ugwuanyi, C. S., Okeke, C. I. O., Nnamani, P. A., Obochi, E. C. \& Obasi, C. C. (2020a). Relative effect of animated and nonanimated powerpoint presentations on physics students' achievement. Cypriot Journal of Educational Science. 15(2), 282291. https://doi.org/10.18844/cjes.v15i2.4647

16. Ugwuanyi, C.S., Nduji, C.C., Elejere, U.C., \& Omeke, N.E. (2020c). Effect of flipped classroom and think pair share strategy on achievement and retention among senior secondary school Physics students. International Journal of Sciences: Basic and $\begin{array}{llrl}\text { Applied } \quad \text { Research } & \text { (IJSBAR), } & \text { 136-148), }\end{array}$ https://www.gssrr.org/index.php/JournalOfBasicAndApplied/article/view/11250/5681

17. Ugwuanyi, C.S., \& Okeke, C.I.O.(2020). Enhancing university students 'achievement in physics using computer-assisted instruction. International Journal of Higher Education 9(5), 115-124. https://doi.org/10.5430/ijhe.v9n5pl15 
18. Ugwuanyi, C. S., Okeke, C.I.O. \& Asomugha, C.G., (2020). Prediction of learners' mathematics performance by their emotional intelligence, self-esteem, and self-efficacy. Cypriot Journal of Educational Science. 15(3), 492-501. http://dx.doi.org/10.18844/cjes.v\%vi\%i.4916

19. Ugwuanyi, C.S., Okenyi, E.C., Ezema, V., \& Amoke, C. (2020d). Effect of digital game-based learning on achievement of primary school pupils in sciences in Enugu State, Nigeria. Journal of Educational Research on Children, Parents \& Teachers, $1(1), 35-44$.

20. Ugwuanyi, C.S., Ugwuanyi, C.C., Ezenwa-Nebife, D.C., Gana, C., Ene, C., Oguguo, B.C., Ikeh, F.E., Okeke, A.O., Nwoye, M.N., Obi, C.N., Anyaegbu, C. \& Agah, J.J. (2019b). Assessment of the efficacy of information communication technology tool on achievement of students in physics and mathematics: A case of repeate d measures. Journal of Engineering and Applied Sciences, 14(13), 4541-4546.

21. UNESCO (2020). The futures of education after COVID-19: Regional dialogue synthesis report. Retrieved from https://en.unesco.org/sites/default/files/synthesis report future of education webnair 1.pdf 
